\title{
Monetary Aggregates and Recent Economic Trends
}

T he level of real economic activity continues below potential, with little change in trend during the past year. The rate of inflation appears to have slowed somewhat since last spring; the rate of increase in consumer prices has slowed more than the rate for wholesale industrial prices. More expansive monetary actions are reflected in the relatively rapid rates of growth in the monetary base and the money supply. Short-term interest rates have declined markedly; interest rates on long-term corporate bonds rose in March but are still below their recent peaks in mid-1970.

Recently there has been greater use of monetary aggregates, particularly various combinations of the money stock, time deposits, and savings deposits, in the formulation and measurement of monetary policy. Time and savings deposits have grown more rapidly than demand deposits in the past year, affecting the relative growth rates of these various monetary aggregates. The growth of time and savings deposits has altered the channels through which credit flows but not necessarily the total volume of credit extended.

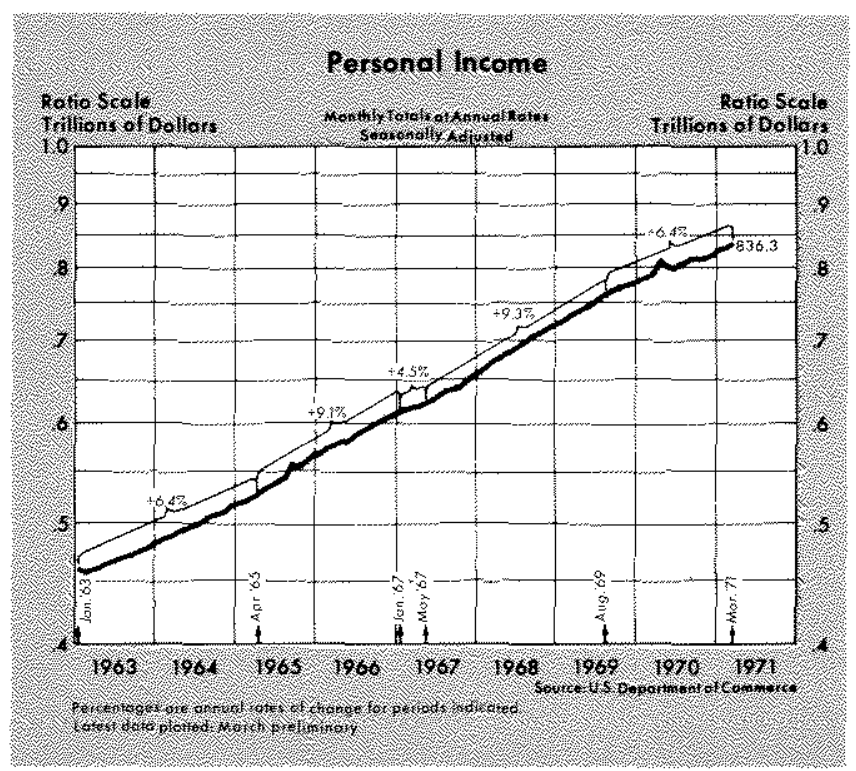

\section{Income, Employment, and Prices}

Personal income has been growing moderately for about a year and a half without a discernible change in trend. Since August 1969, personal income has risen at about a 6 per cent annual rate, after rising at a 9 per cent rate in the previous two years. The 9.5 per cent rate of increase in personal income in the past three months partially reflects a recovery from work stoppages in the automobile industry and preparation for other possible strikes later this year.

Estimated retail sales increased 7 per cent in the year ending March 1971, compared with a 3.7 per cent annual rate of increase from July 1969 to March 1970. Considering price trends, it appears that there has been essentially no change in retail sales activity for a long time. Industrial production has declined at about a 3.3 per cent anmual rate since July 1969. A sharper contraction last fall during the strike has since been offset by the increase since November 1970 .

Total civilian employment has remained essentially unchanged during the past year. Payroll employment declined about one per cent in the past year. Payroll

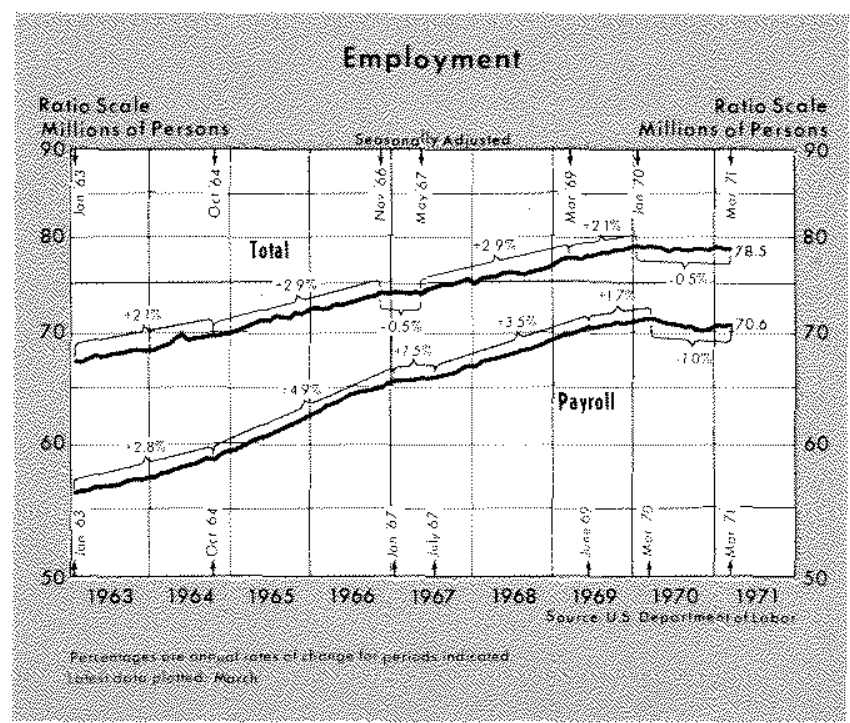


employment generally falls faster than total civilian employment during periods of contraction, and increases faster during periods of expansion. The per cent of unemployed persons out of work 27 weeks or longer rose from about 8 per cent in February 1970 to nearly 8.3 per cent in February 1971.

Manufacturing earnings, adjusted for changes in consumer prices, overtime, and the industrial composition of the labor force, have risen at a 2.2 per cent rate during the past year, compared with no change in the year ending October 1970. Wage increases have been unequally distributed among workers in different industries. Hourly eamings in retail trade increased 5 per cent in the past year. Hourly earnings in contract construction rose 9 per cent in the past twelve months, compared with a 9.5 per cent annual rate of increase in the sevenmonth period ending March $1970{ }^{1}$

Reduction in the rate of inflation has been proceeding gradually. Consumer prices rose at a 1.5 per cent annual rate from December to February and at a 4 per cent rate from June to February, compared with a 6 per cent rate from June 1969 to June 1970. Whole-

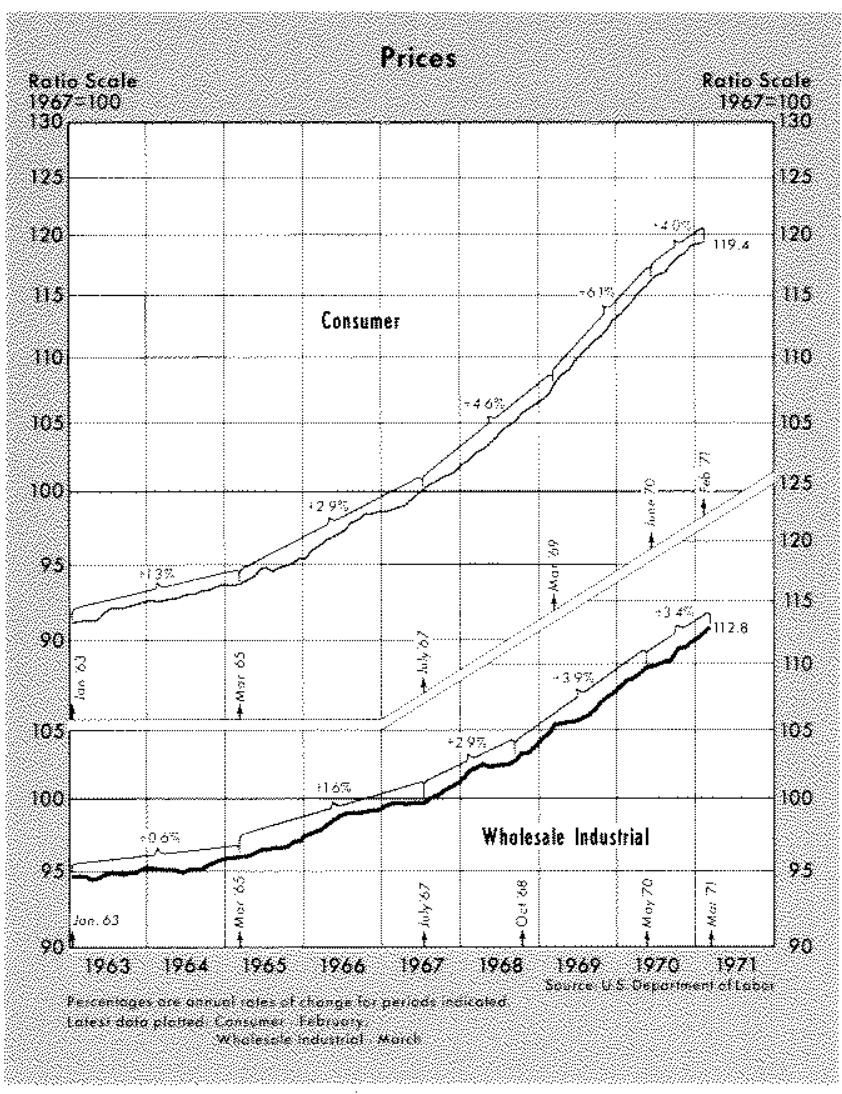

The rates of change in hourly earnings in retail trade and contract construction are not adjusted for changes in consumer prices or overtime. sale industrial prices have increased at a 3.4 per cent rate since May 1970 , compared with a 3.9 per cent rate in the nineteen-month period ending May 1970.

\section{Recent Monetary and Interest Rate Developments}

Monetary stimulation to the economy has become greater in the last year. The money stock, defined to include private demand deposits and currency in the hands of the public, has increased at an 8.2 per cent annual rate in the past four months, after rising at about a 6 per cent rate in the previous nine months. By comparison, money increased at a 3 per cent rate from January 1969 to February 1970, and at an average 4.7 per cent rate from 1963 to 1968 .

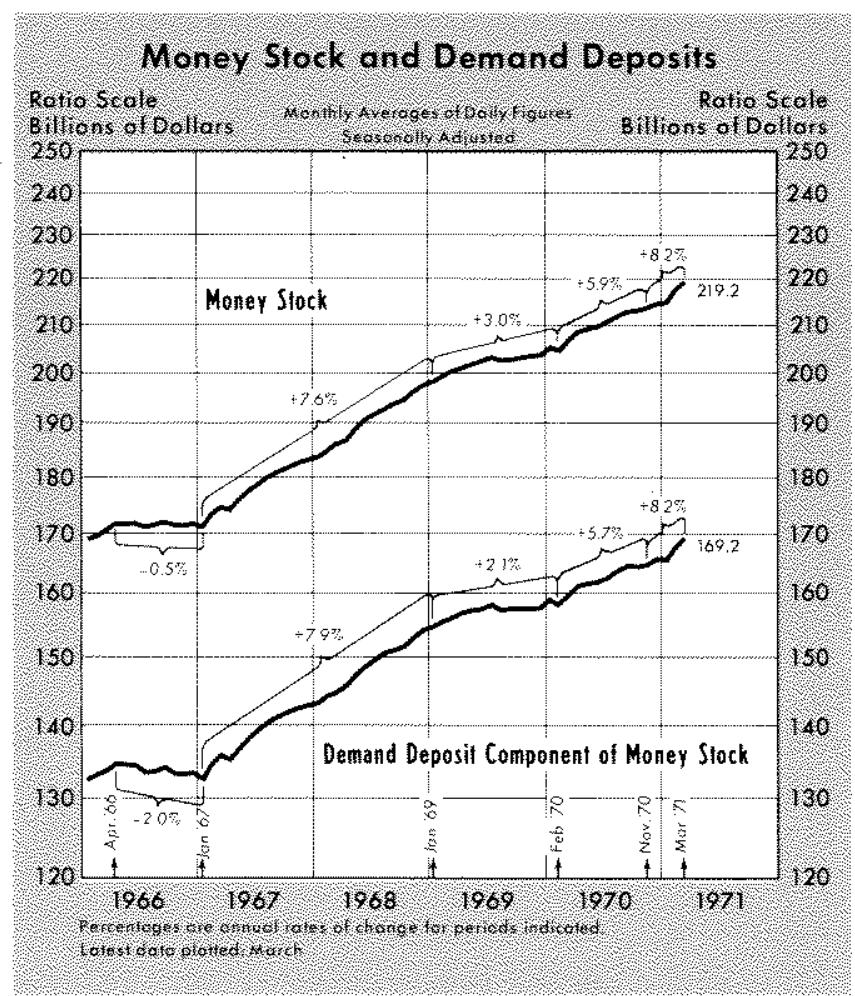

More expansive monetary actions have also been reflected in the growth of the monetary base. The base has increased at a 7.6 per cent annual rate since February 1970 and at about an 11 per cent rate in the past four months. By comparison, the base increased at a 3.7 per cent trend rate from 1957 to 1969 . The largest source component of the base, Federal Reserve credit, has risen at an 8.8 per cent annual rate since February 1970 and at a 14.2 per cent rate over the past four months, compared with a trend rate of almost 8 per cent from 1957 to 1969 .

Short-term market interest rates have declined markedly in recent months, reflecting both a weak- 


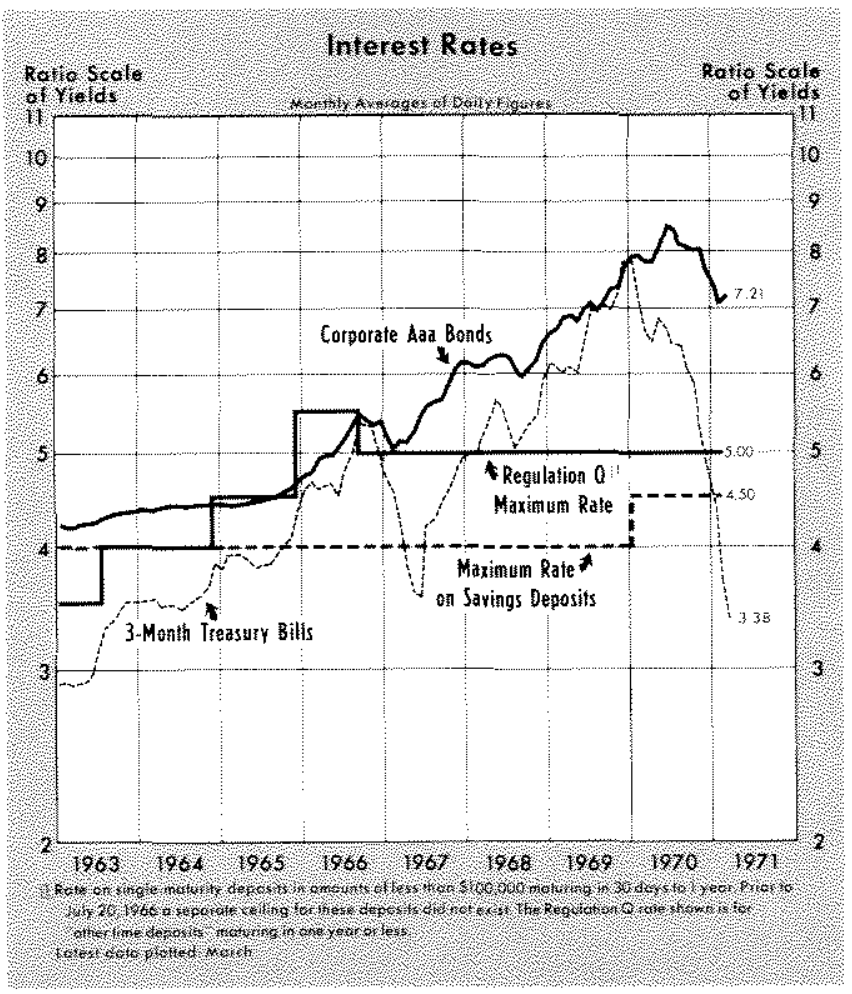

ness in demand for credit accompanying the slack in economic activity and the more expansionary monetary developments. Three-month Treasury bill rates averaged 3.38 per cent in March, down from 4.4 per cent in January 1971 and 6.63 per cent in March 1970. Responding to the weakness in demand for loans relative to supply, banks have lowered the prime interest rate which they charge to their highest-rated business customers ten times since mid-September. The most recent decline (late March) was to 51/4 per cent, compared with 8 per cent last spring and summer.

Interest rates on longer-term issues have declined much less than rates on short-term obligations, reflecting continued great inflationary expectations and a desire by some borrowers to lengthen their debt to improve their liquidity. Yields on long-term Government bonds averaged 5.71 per cent in March, down about 20 basis points from January 1971. Last June interest rates on these bonds averaged about 7 per cent. Yields on seasoned Aaa corporate securities rose in March, averaging 7.21 per cent but still down about 130 basis points from June 1970 .

\section{Alternate Monetary Aggregates}

In addition to continued use of interest rates and short-term credit-market conditions, recently there has been greater use of the money supply and various other measures of liquidity in the formulation and measurement of monetary policy." Currently, policy discussions frequently include references to the growth rates of three measures of the money supply:

$$
\begin{aligned}
M^{1}= & \text { demand deposits plus currency held by the } \\
& \text { public; } \\
M^{2}= & M^{1} \text { plus time deposits at commercial banks } \\
& \text { other than large negotiable certificates of } \\
& \text { deposit; } \\
\mathrm{M}^{3}= & \mathrm{M}^{2} \text { plus all savings and loan shares and } \\
& \text { mutual savings bank deposits. }
\end{aligned}
$$

The growth rates of these three aggregates have diverged widely in recent years, which means that on the surface they have not provided consistent information regarding the thrust of monetary actions. These divergent growth rates have been largely the result of substantial swings in market interest rates, compared to the maximum rates that banks, savings and loan associations, and mutual savings banks are permitted to pay on deposits. ${ }^{4}$

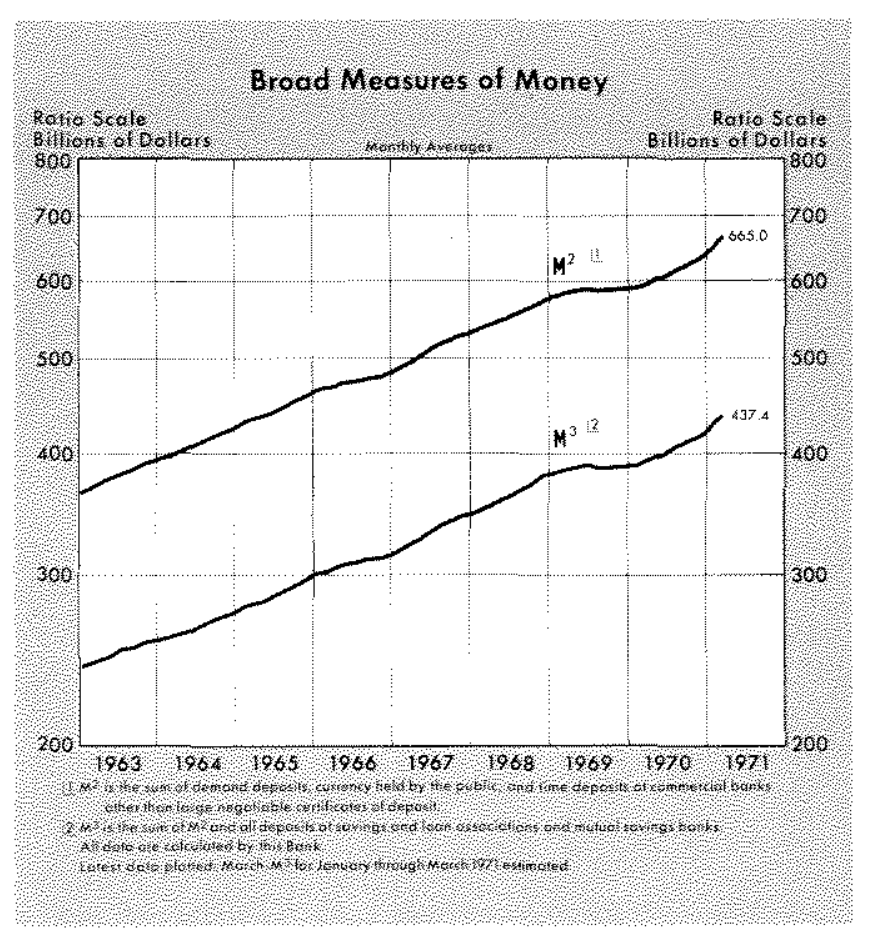

"The role of the monetary aggregates is discussed in "Monetary Aggregates and Money Market Conditions in Open Market Policy," Federal Reserve Bulletin (February 1971), pp. 79-104.

For expositional purposes, total time deposits at commercial banks minus large negotiable certificates of deposit are referred to as "net time deposits."

Interest rate ceilings on deposits at banks which are members of the Federal Reserve System are established tunder Federal Reserve Regulation Q. Under the Interest Rate Control Act of 1966 , ceilings at Federally-insured nonmember banks and mutual savings banks are set by the Federal Deposit Insurance Corporation; the Federal. Fome Loan Bank Board controls the ceiling rates paid at its 


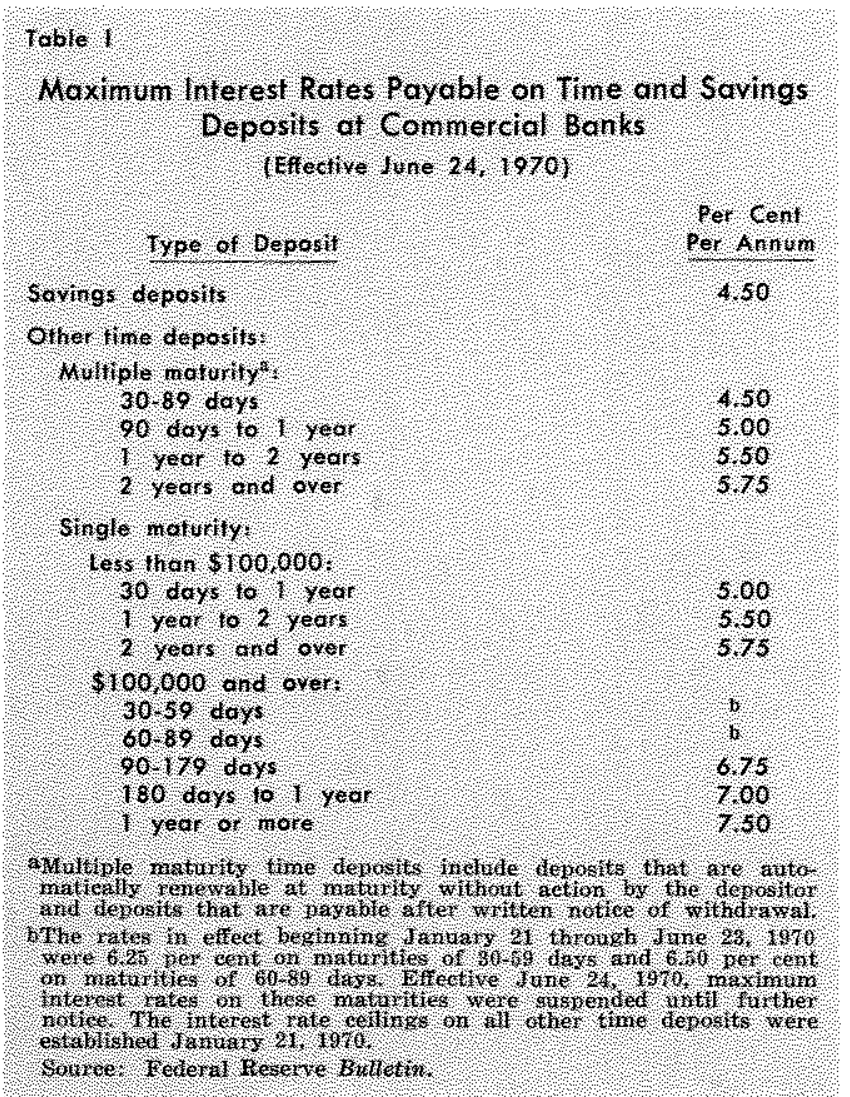

The ceiling rates on various types of time and savings deposits currently in effect at commercial banks are shown in Table I. As indicated in the table, the ceiling rates on large negotiable CD's bearing maturities of one month to three months were suspended in June last year. The ceiling rates on other time and savings deposits were last increased in January 1970 , with the maximum interest rates allowed on most types of savings and small time deposits being raised by one-half to three-quarters of one per cent. The maximum rates payable on large negotiable CD's were raised by increments ranging from three-quarters of one per cent to one and one-quarter per cent, depending on maturity.

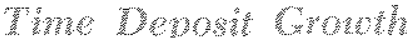

Total time deposits at commercial banks generally grew very rapidly in the 1960 's, except for 1969 . During the three years ending December 1968, both total time deposits and time deposits excluding large CD's rose at a rapid 12 per cent average annual rate.

member savings and loan associations; and the Federal Reserve Board can prescribe different rate cellings for time deposits on the basis of the amount of deposit. These three regulatory agencies are required to consult with each other when considering changes in the celling rates. This act is scheduled to expire June 1,1971 .
The accompanying chart, which shows the ratio of time deposits to demand deposits, indicates that time deposits declined more rapidly than demand deposits during the period of restrictive monetary policy in 1969 and early 1970. The decline in time deposits in 1969 and early 1970 was caused by market interest rates rising well above the rates at which commercial banks were able to compete under Regulation $Q$ ceilings.

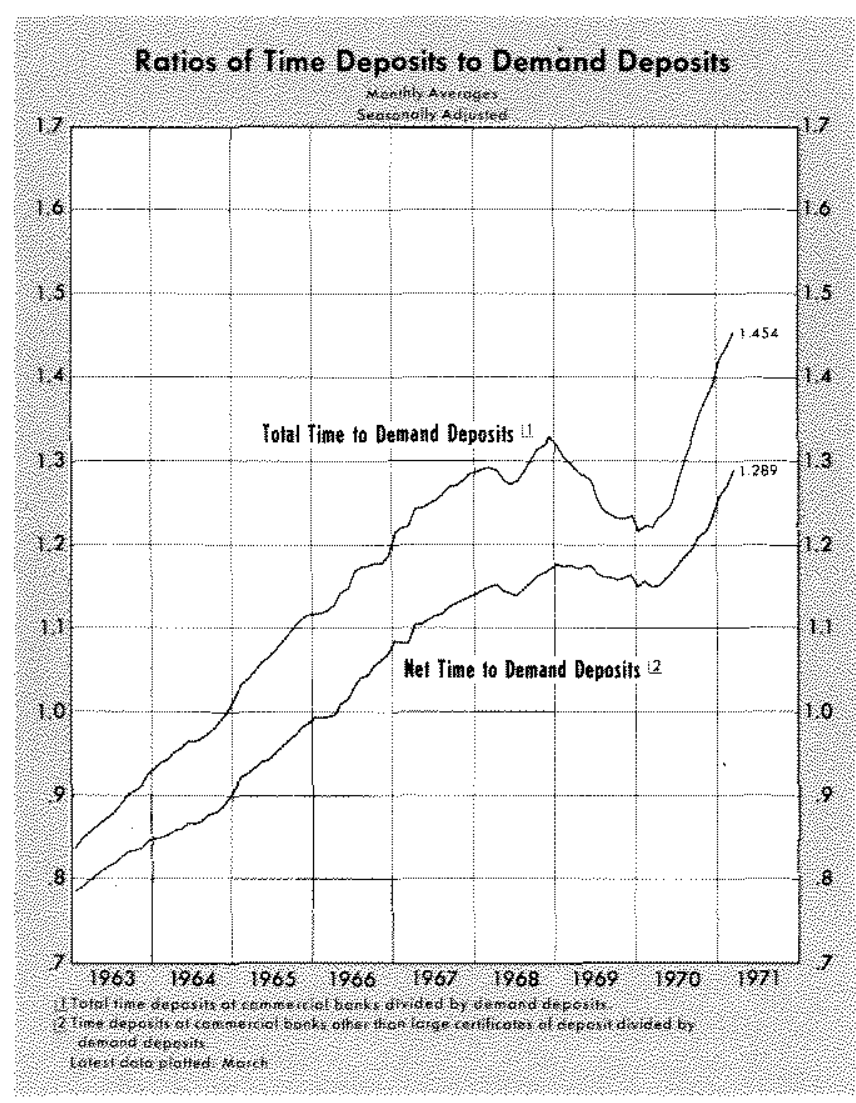

Early last year, short-term market interest rates began to decline, and Regulation Q ceiling rates on certain time deposits were raised. Due to this combination of developments, time deposits began a period of rapid increase which has continued to the present time. The growth of demand deposits also accelerated in 1970 as monetary actions became more stimulative; however, the much more rapid growth of time deposits is reflected in a significant increase in the ratio of time to demand deposits.

It is of interest to note the trend of the ratio of time to demand deposits in the year of reintermediation since early 1970 , compared to the trend of this ratio in the six years prior to the inception of disintermediation in early 1969. The ratio of total time deposits to demand deposits rose at a 17 per cent ammual rate from February 1970 to March 1971, much faster than 
the 8 per cent annual rate of increase in this ratio from 1963 through 1968 when monetary policy was highly stimulative, but Regulation $Q$ interest ceilings were impinging only for brief periods.

The series "time deposits at commercial banks" consists of several distinct types of interest-bearing deposits offered by banks. The various types of time deposits differ substantially with respect to size limitations, frequency of interest payments, maximum rates payable, and negotiability. It has recently become common practice to separate large negotiable certificates of deposit $(\$ 100,000$ minimum denomination) from all other time deposits in analyzing the factors infuencing time deposit growth. These two major classes of time deposits will be discassed separately below.

Large Certificates of Deposit - During the past few years, the outstanding volume of large negotiable CD's at large commercial banks has been subject to sharp swings, as market interest rates on substitute instruments fluctuated widely compared to the maximum rates banks were permitted to pay on these deposits. In 1969, market interest rates on commercial paper and U.S. Treasury bills were much higher than the ceiling rates on bank deposits. As a result, corporations, state and local governments, and others who hold large dollar amounts of short-term interest

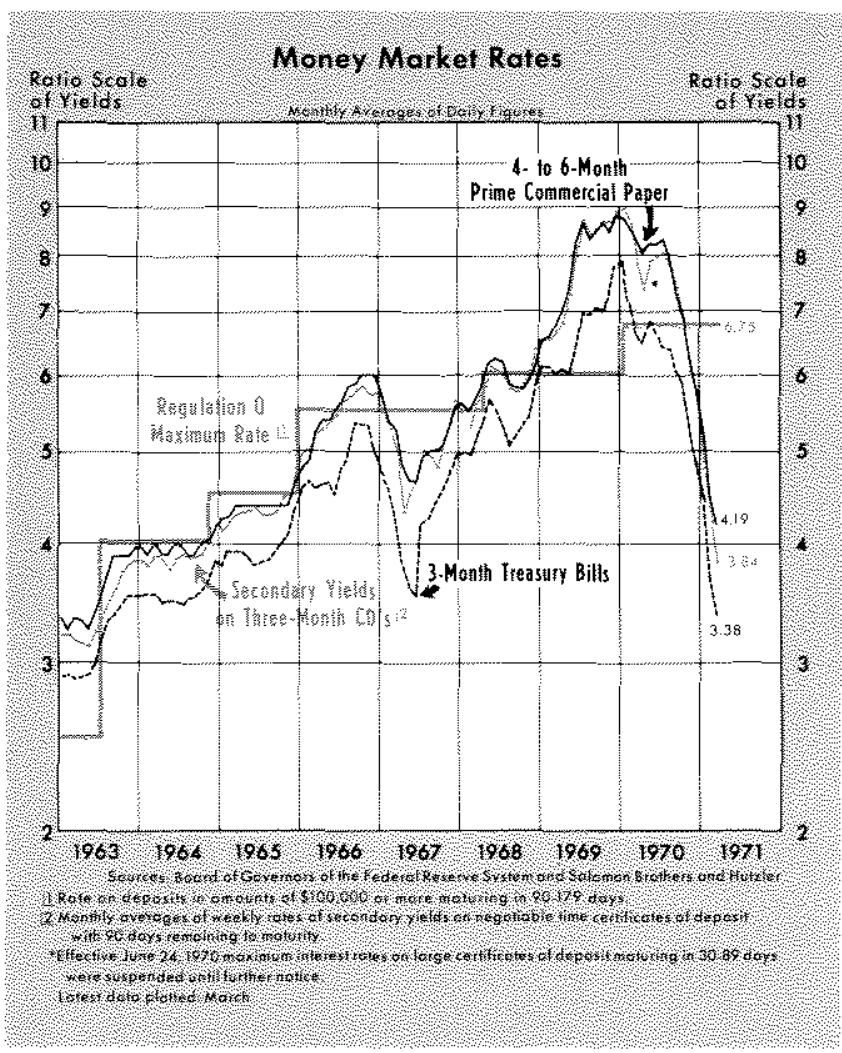

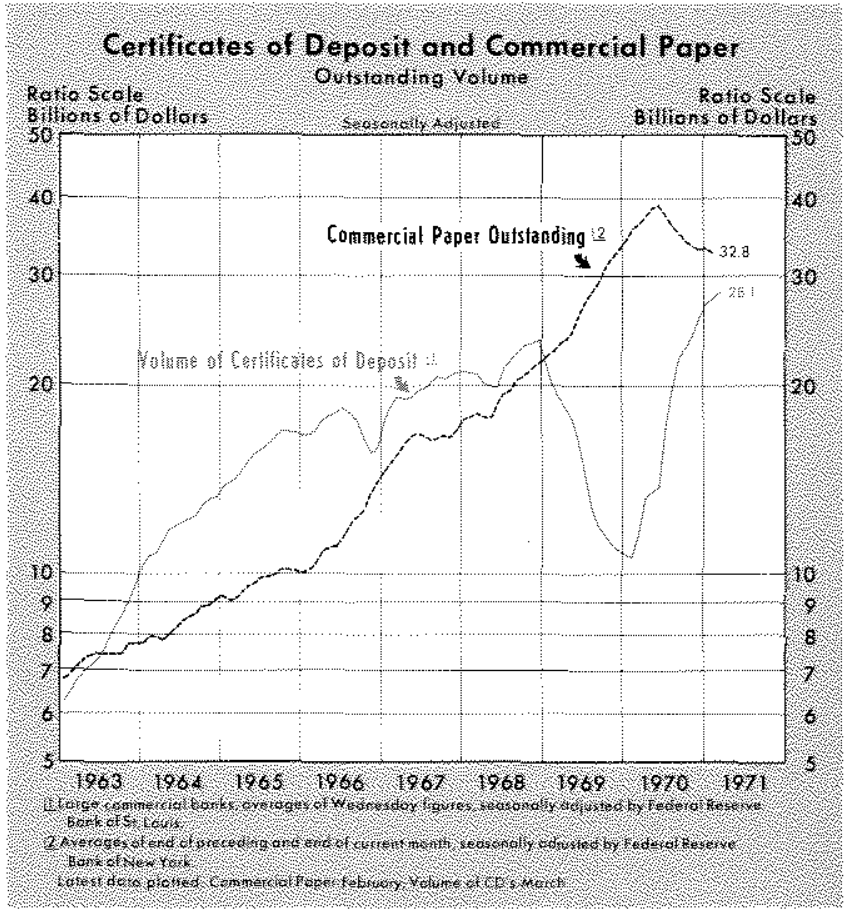

bearing assets turned to lending directly through the commercial paper market and to direct ownership of U.S. Treasury bills.

As shown in the charts of commercial paper and $C D$ volumes and rates, the growth of outstanding commercial paper accelerated sharply in 1969 as the yield on this instrument rose relative to the ceiling on CD's. The rise in conmercial paper volume closely mirrored the decline in $\mathrm{CD}$ volume. For several years prior to 1969 , both CD's and commercial paper had grown steadily and rapidly. In the first half of 1969 the rates on commercial paper moved more than two percentage points above the official ceiling rates which could be paid on large CD's. Large CD's at commercial banks dropped over $\$ 12$ billion during 1969 , while growth of commercial paper accelerated and the outstanding volume rose over $\$ 11$ billion in 1969.

Early in 1970 the trends were reversed as a result of changes in the relative yields of these instruments. In January the Regulation $Q$ interest rate ceilings on these large time deposits were raised by increments of three-fourths to one and one fourth percentage points, and in June the ceiling rates were completely suspended on certain maturities of large CD's. At the same time, the yield on commercial paper declined along with other short-term market interest rates. Also, in October 1970 reserve requirements were imposed on commercial paper issued by bank holding companies, and there was concem in the financial community about the risk associated with commercial 
paper issued by some corporations because of their financial difficulties. The volume of CD's recovered $\$ 17$ billion in 1970 and early 1971, while from May 1970 to February 1971 the volume of commercial paper outstanding dropped $\$ 6$ billion.

Net Time Deposits-The growth of time deposits at commercial banks net of large negotiable certificates of deposit has also been affected by the level of market interest rates relative to the ceiling rates, but to a lesser extent than CD's. These net time deposits declined somewhat from mid-1969 to early 1970 before resuming a rapid upward trend. From February 1970 to March 1971 net time deposits rose at an 18 per cent annual rate, following a 1 per cent rate of change from December 1968 to February 1970, and a 13 per cent rate of increase from December 1966 to December 1968. These broader measures of money plus near-monies, in addition to the narrowly defined money stock, may be considered by policymakers in assessing the influence of monetary actions on economic activity. Thus, it is useful to look at the relative growth of net time deposits and deposits at thrift institutions in recent years.

\section{Savings Deposits}

Household and small business savings deposits at commercial banks, savings and loan associations, and mutual savings banks are generally considered to be close substitutes for each other, although their growth rates have diverged substantially on occasion. During the 1950 's savings and loan shares and mutual savings bank deposits rose relative to time deposits at com-

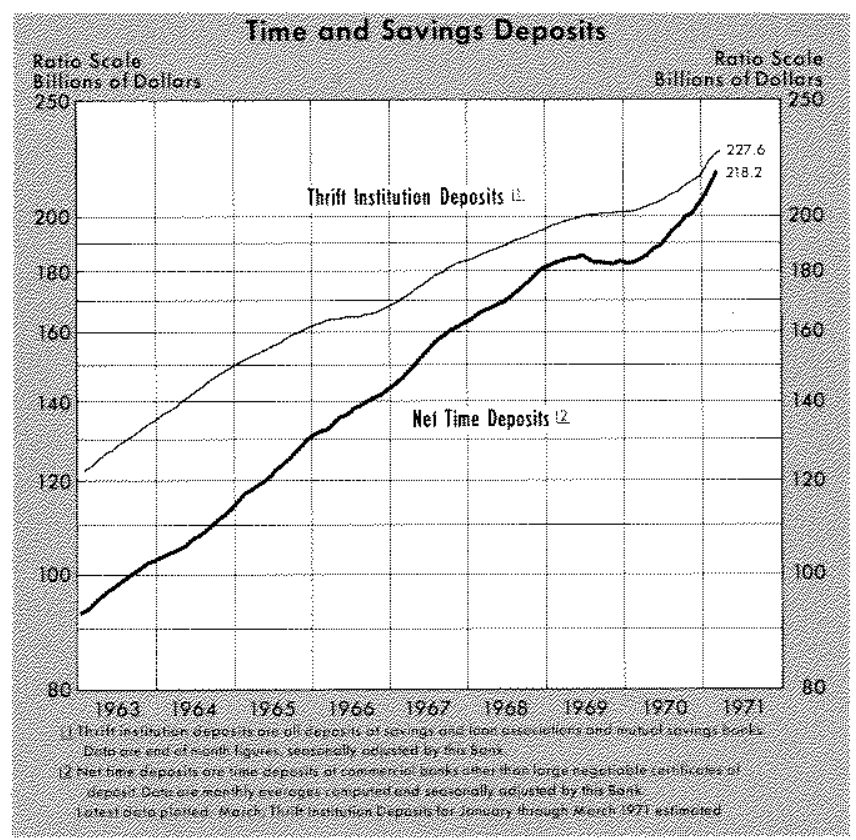

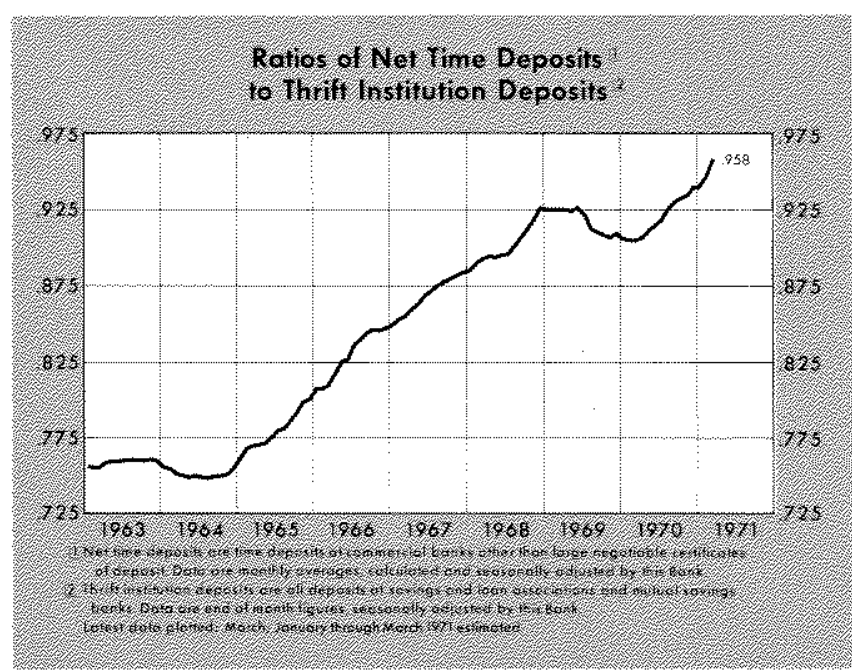

mercial banks; however, in the decade of the Sixties, net time deposits at commercial banks have risen more rapidly. As shown in a chart of the ratio of net time deposits to the total of deposits at thrift institutions, from mid-1964 to the end of 1968 the proportion of household and small business savings flowing into commercial banks rose rather steadily relative to such deposits in the thrift institutions, that is, savings and loan associations and mutual savings banks.

On balance since the end of 1968 , the ratio of net time deposits to deposits in thrift institutions has not risen significantly, although this ratio has recently been following an upward trend. All of such deposits have risen rapidly from early 1970 to the present, following the increase in the ceiling rates on savings deposits and the general decline in market interest rates. In the period February 1970 to March 1971, the volume of net time deposits at commercial banks rose 17 per cent annal rate, savings and loan shares increased 13 per cent, and mutual savings bank deposits increased 9 per cent.

A factor contributing to the very rapid reintermediation of deposits at financial intermediaries in 1970 was establishment of a $\$ 10,000$ minimum denomination on the purchase of U.S. Treasury bills. Effective beginning with the Treasury bill auction of March 2, $1970, \$ 10,000$ became the smallest denomination of Treasury bills offered. The smallest denomination of Treasury notes and bonds, which carry maturities greater than one year, has continued to be $\$ 1,000$.

The effect of raising the minimum denomination of Treasury bills to $\$ 10,000$ is that individuals and small businesses with less than $\$ 10,000$ increments of savings to lend can no longer obtain these highly liquid 


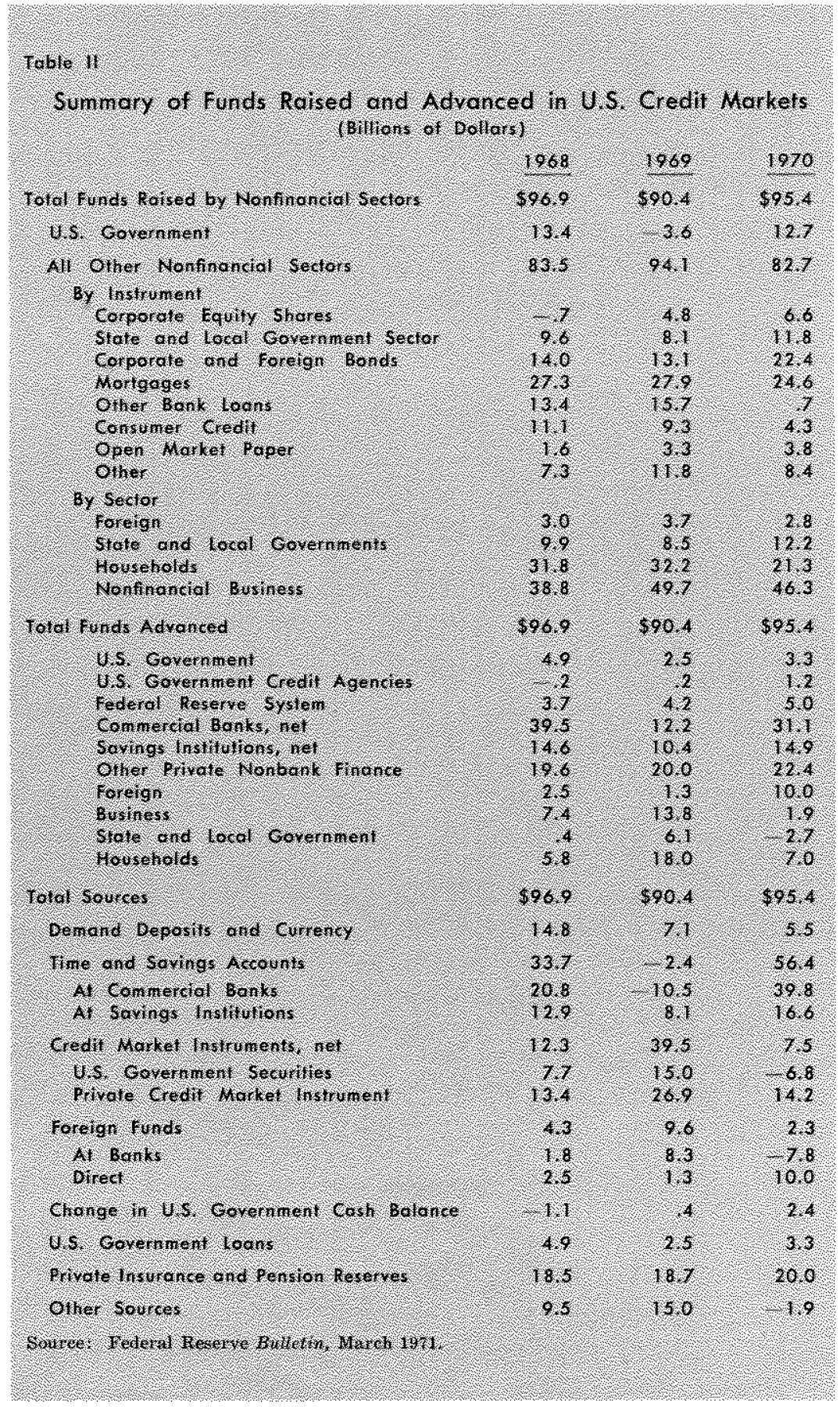

volved, commercial banks and thrift institutions were undoubtedly beneficiaries of this Treasury Department action.

\section{Credit Flows and Reintermediation}

The disinternediation - reintermediation process shows up dramatically in the Flow of Funds Accounts for the past three years. Table II shows summary data for these flows in the past three years. According to those accounts, private holdings of time and savings deposits increased in 1970 by the largest amount ever recorded after declining slightly in 1969. Most of the reversal is accounted for by deposits at commercial banks, specifically corporate holdings of negotiable CD's, state and local government holdings of both CD's, and other time deposits. Households resumed acquisition of time deposits at commercial banks and savings and loan associations. The other side of the reintermediation process is represented by a decline in the holding of credit market instruments. Households and state and local governments switched from rapid acquisition of U.S. Government securities to liquidation. Also, nonfinancial corporate business moved from rapid acquisition of open market paper to liquidation.

Along with an easier monetary policy in 1970 , total funds raised by nonfinancial sectors was larger than in 1969, but not as much as in 1968. U.S. Govemment borrowing resumed levels of earlier periods after supplying net funds in 1969. This increased borrowing by securities. Prior to this action by the Treasury, individuals and small businesses had acquired significant holdings of Treasury bills, usually with maturities of six months to one year. After March 2, 1970 such holdings in less than $\$ 10,000$ increments could not be renewed as they matured, so the individuals were forced to accept repayment from the Treasury for maturing securities. Small savers then sought alternative sources to earn interest on short-term funds. Although it is not possible to identify the amounts in- the U.S. Govermment of $\$ 16$ billion was offset by an $\$ 11$ billion decline in household borrowing.

Lenders altered their participation in the credit markets in 1969. Conmercial banks recovered from a low level of lending, while businesses and households reduced sharply the amount of funds they advanced to the credit maket. Foreign lenders advanced directly an unusually large amount of funds during 1970, principally through the acquisition of U.S. Gov- 
emment securities. However, a large part of these funds represents at transfer of foreign holdings out of Eurodollars and other financing assets as well as a reduction in foreign exchange liabilities held in the U.S,

\section{Summary}

Production and employment remain below capacity levels, with little change in trends in the past year after allowance for strike effects. Inflation remains strong and is receding slowly in response to the downward pressure from excess capacity. Monetary actions have become more expansionary in the last fifteen months, with a view to stimulating growth in sales, production, and employment without intensifying inflationary pressures.

There has recently been a greater use of monetary aggregates, composed of the narrowly defined money supply and time and savings deposits, in the formulation and measurement of monetary policy. Time and savings deposits increased at a rapid rate in the past year, causing a divergence between the growth rates of the money stock and other monetary aggregates. Individuals and firms invested a larger share of their wealth in time and savings deposits as market interest rates fell relative to the interest ceilings of these deposits. Total credit, total funds raised by borrowers over a period of time, has not been affected as much as the channels of credit flows during the period of reintermediation in the past year.

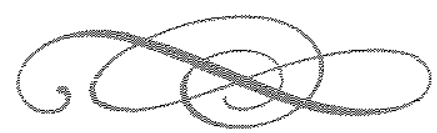

